Die

\title{
Breupiijhen Bseję̧e
}

betreffend

\section{Dientfeinkummen, Bathegehalt}

unb

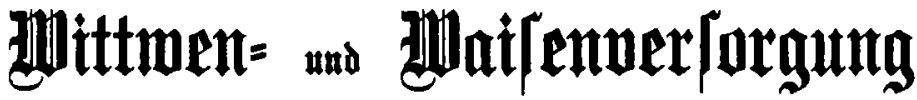 \\ ber}

\section{Bolfsidullethrer.}

\author{
Für ben praftifden (sebraud \\ erläutert \\ bon
}

Dr. Cenra Fauf,

Megietungorath.

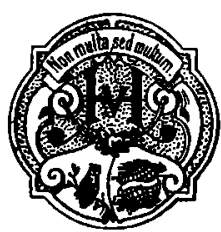

(Prtí gebunden $\mathfrak{M}$. 2,80, von 10 Exemplaren $a b$ à $\mathfrak{M}$. 2,40.

Bexlin 1900.

3. 3. Seines Berlag. 
